Proc. Estonian Acad. Sci. Biol. Ecol., 2006, 55, 3, 216-227

\title{
Freshwater sponges in Estonia: genetic and morphological identification
}

\author{
Tiiu Roovere ${ }^{\mathrm{a}, \mathrm{b}}$, Annika Lopp ${ }^{\mathrm{a}}$, Tõnu Reintamm ${ }^{\mathrm{a}}$, Anne Kuusksalu $^{\mathrm{a}}$, \\ Evelyn Richelle-Maurer ${ }^{\mathrm{c}}$, and Merike Kelve ${ }^{\mathrm{a}^{*}}$

\footnotetext{
${ }^{a}$ National Institute of Chemical Physics and Biophysics, Akadeemia tee 23, 12618 Tallinn, Estonia

b Tallinn University of Technology, Ehitajate tee 5, 19086 Tallinn, Estonia

${ }^{c}$ Laboratoire de Physiologie Cellulaire, IBMM-CP 300, Unversité Libre de Bruxelles, Rue des Professeurs Jeener et Brachet 12, B 6041 Charleroi, Belgium
}

Received 7 April 2005, in revised form 13 May 2005

\begin{abstract}
Samples of freshwater sponges (Porifera, Demospongiae, Haplosclerida, suborder Spongillina) were collected at three sites in South Estonia in the Sulaoja and Võhandu rivers. A molecular approach based on the sequencing of the extended D3 domain of the 28S rDNA was used for the confirmation of the identity of sponge species. The DNA analysis showed the presence of three spongillid species in Estonia: Ephydatia fluviatilis, Ephydatia muelleri, and Spongilla lacustris. Identification of the samples by classical morphological studies of their skeleton spicules using scanning electron microscopy was performed in parallel.
\end{abstract}

Key words: Estonia, freshwater sponges, identification, 28S rDNA, electron microscopy.

\section{INTRODUCTION}

Sponges are the most ancient multicellular animals, having existed for more than 580 million years (Müller et al., 2004). At least 15000 species are classified into the phylum Porifera, which is divided into three classes, the Hexactinellida, the Demospongiae, and the Calcarea, based on the nature of their mineral skeleton. Sponges have colonized most aquatic habitats from polar seas to tropical waters and approximately 150 species (spongillids) have become adapted to freshwater (Manconi \& Pronzato, 2002).

\footnotetext{
* Corresponding author, merike@kbfi.ee
} 
Sponges are sessile filter-feeding organisms, lacking true tissues and organs. Still sponges and higher metazoan phyla share a variety of metabolic pathways, structural elements, and molecules, which can be used for understanding the evolutionary aspects of biochemical systems in mammals. Sponges are also of great interest for the pharmaceutical industry as they contain a large variety of unique bioactive compounds. These compounds are often synthesized by unknown biochemical pathways.

We have discovered two novel, non-traditional ATP consuming enzymes in marine sponges (Kuusksalu et al., 1995; Reintamm et al., 2003), products of which may be considered as signal-transducing molecules. One of these enzymes, the ATP N-glycosidase, characteristic of the marine sponge Axinella polypoides, was also found in several freshwater sponges collected in Belgium (Kelve et al., 2004).

A few spongillids (class Demospongiae, order Haplosclerida, suborder Spongillina) have been found in Estonia. Dybowski (1878) described three species from different collecting sites in Estonia: Spongilla (now Ephydatia) fluviatilis, S. lacustris, and S. erinaceus. In the opinion of Prof. Riikoja, although suggested many decades later, the species that Dybowski had called S. erinaceus was Ephydatia muelleri (Riikoja, 1955). Mühlen \& Schneider (1920) identified S. lacustris in Lake Vorrtsjärv. Since then only a few pieces of data about the presence of the above-mentioned sponge species in Estonian waters have been reported (Riikoja, 1955; Ristkok \& Ruse, 1962; Ristkok, 1994; Timm, 1998). Presumably up to six different sponge species could be found in Estonian lakes and rivers (Järvekülg, 1995).

The Estonian freshwater sponges were initially identified by their morphological characters (Dybowski, 1878), including their mineral skeleton. Now molecular approaches, usually based on $18 \mathrm{~S}$ rDNA sequences and/or partial $28 \mathrm{~S}$ rDNA sequences, have been developed for the analysis of the sponge phylogenetic relationship. The same methodology can be used for the confirmation of the identity of sponge species.

In this study we used a DNA region containing a variable D3 domain of the large subunit (28S) of the nuclear ribosomal RNA gene for the identification of spongillids collected in different locations in Estonia. The identity of the samples was additionally confirmed by electron microscopy of their skeletal elements (spicules).

\section{MATERIALS AND METHODS}

\section{Sponge samples}

Samples were collected at three sites in South Estonia: Krüüdneri (the Sulaoja River), Sulbi (the Võhandu River), and Parmuveski (the Võhandu River) on 22 September and 6 October 2004. The samples were transported to the laboratory 
in river water. Aliquots from each sample were taken for skeletal structure analysis, and the rest of the material was frozen in liquid nitrogen and stored at $-70^{\circ} \mathrm{C}$.

Freshwater type specimens from Prof. Richelle-Maurer's collection in Brussels Free University served as references. All of them had been restarted from purified gemmules in vitro.

\section{Spicule preparations}

The nitric acid technique was used to dissolve the sponge tissue (van Soest, 2001). After repeated washing procedures the spicules were rinsed with and resuspended in $96 \%$ ethanol.

\section{Electron microscopy}

The spicule suspension in ethanol was placed onto a specimen holder and optionally coated with gold in a Cressington 108auto Sputter Coater. The specimens were examined and photographed in a Philips XL30 ESEM scanning electron microscope, high vacuum mode, using either BSE detector with accelerating voltage $15 \mathrm{kV}$ or $\mathrm{SE}$ detector with accelerating voltage $2 \mathrm{kV}$ (for the gold coated specimens).

\section{Extraction of genomic DNA}

A CTAB technique (Murray \& Thompson, 1980) proved to be suitable for the extraction of sponge genomic DNA. In brief, $0.1 \mathrm{~g}$ of frozen sponge tissue was ground to a fine powder with liquid nitrogen, added to $300 \mu \mathrm{L}$ sterile water and $500 \mu \mathrm{L}$ cetylmethylammonium bromide (CTAB) extraction buffer $(20 \mathrm{~g} / \mathrm{L}$ CTAB, 1.4 M NaCl, $20 \mathrm{mM}$ EDTA, $0.1 \mathrm{M}$ Tris-HCl, $\mathrm{pH} 8$ ) together with $20 \mu \mathrm{L}$ proteinase $\mathrm{K}$ solution $(20 \mathrm{mg} / \mathrm{mL})$ and incubated for $90 \mathrm{~min}$ at $65^{\circ} \mathrm{C}$. Total genomic DNA was then extracted twice with an equal volume of chloroform and precipitated with 2 volumes of CTAB precipitation buffer $(5 \mathrm{~g} / \mathrm{L} \mathrm{CTAB}, 0.04 \mathrm{M} \mathrm{NaCl})$. The samples were incubated at $4{ }^{\circ} \mathrm{C}$ for $60 \mathrm{~min}$, pelleted by centrifugation, and the precipitate was dissolved in $350 \mu \mathrm{L} 1.2 \mathrm{M} \mathrm{NaCl}$. After a chloroform treatment the DNA was precipitated by adding 0.6 volumes of isopropanol, then pelleted and washed with $500 \mu \mathrm{L} 70 \%$ ethanol. The DNA precipitate was resuspended in $100 \mu \mathrm{L}$ sterile water, and its concentration was determined spectrophotometrically at $260 \mathrm{~nm}$.

\section{PCR amplification}

The D3 domain of the 28S rDNA together with approximately $150 \mathrm{bp}$ of 3' core sequence was amplified using the primer pair 5'-GAC CCG TCT TGA AAC 
ACG GA and 5'-TCG GAG GGA ACC AGC TAC TA. The PCR amplifications were performed in $50 \mu \mathrm{L}$ reaction volumes containing about 50 ng genomic DNA; buffer A (20 mM Tris- $\mathrm{HCl}, \mathrm{pH} 9.0$ at $25^{\circ} \mathrm{C}, 50 \mathrm{mM} \mathrm{KCl}, 0.1 \mathrm{mg} / \mathrm{mL}$ gelatine); $2.5 \mathrm{mM} \mathrm{MgCl} 2 ; 200 \mu \mathrm{M}$ each of dATP, dCTP, dGTP, and dTTP; $0.4 \mu \mathrm{M}$ of each primer and 1.25 units of Taq polymerase FirePol (Solis, Estonia). The DNA was denatured at $95^{\circ} \mathrm{C}$ for $1 \mathrm{~min}$, followed by 35 cycles of denaturation at $94^{\circ} \mathrm{C}$ for $45 \mathrm{~s}$, annealing at $55^{\circ} \mathrm{C}$ for $45 \mathrm{~s}$, and extension at $72^{\circ} \mathrm{C}$ for 1 min with a final extension at $72^{\circ} \mathrm{C}$ for $1 \mathrm{~min}$.

The PCR results were checked by electrophoresis of the products in 1.5\% agarose gel. The amplification products were purified using a JetQuick PCR Purification Kit (Genomed, Germany).

\section{Sequencing}

The amplified DNA fragments were directly sequenced using a Dyenamic ET Terminator Cycle Sequencing Kit (Amersham Biosciences, GE Healthcare) and an ABI 310 automated sequencer (Applied Biosystems), according to the recommended protocol. The sequences were edited using the program Sequencer 3.0 (Applied Biosystems), and the sequence alignment was performed manually, using the program BioEdit v.7.0.4 (Tom Hall, Ibis Therapeutics, Carlsbad, CA; http://www.mbio.ncsu.edu/BioEdit/).

\section{RESULTS}

\section{DNA based sponge identification}

A fragment of approximately 340 nucleotides corresponding to the D3 domain of sponge $28 \mathrm{~S}$ rDNA together with the highly conserved region of approximately 150 bases adjacent to the 3' end of this domain (an extended D3 domain) was amplified from each sponge sample. The set of reference sponges from Belgium included four common members of the family Spongillidae (suborder Spongillina (Demospongiae, Haplosclerida)): Ephydatia fluviatilis, Ephydatia muelleri, Eunapius fragilis, and Spongilla lacustris. In the case of Ephydatia fluviatilis three individual strains $\alpha, \beta$, and $\delta$ were analysed. The sequences of the amplified fragments are shown in Fig. 1.

The comparison of the nucleotide sequences revealed several variable positions in the amplified DNA fragments. It means that the $28 \mathrm{~S}$ rDNA fragment chosen to distinguish between different sponge species was adequate for the purpose. At the same time no strain differences were resolved as the extended D3 domains of 28S rDNA from $E$. fluviatilis $\alpha, \beta$, and $\delta$ strains were identical. Accordingly, additional DNA analysis is needed to distinguish between the individual strains of the same species. 
E. fluviatilis

E. muelleri

S. lacustris

E. fragilis
gaccogtcttgaaacacggacCAAGGAGTGCAACATGCGCGCGAGTCTTT

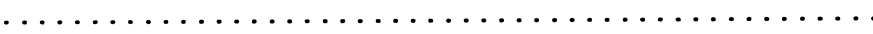

$\cdots \cdots \cdots \cdots \cdots \cdots$

$\ldots \ldots \ldots \ldots \ldots \ldots \ldots \ldots \ldots \ldots \ldots \ldots \ldots \ldots \ldots \ldots \ldots \ldots \ldots \ldots \ldots$

$\begin{array}{lllll}60 & 70 & 80 & 90 & 100\end{array}$

$\ldots|\ldots| \ldots|\ldots| \ldots|\ldots| \ldots|\ldots| \ldots|\ldots| \ldots|\ldots| \ldots \mid$

GGGTGAGACGAAAAGCCCTGTGGCGCAATGAAAGTGAAGCGTCGGCTTGC

E. fluviatilis

E. muelleri

S. lacustris

E. fragilis
120

130

140

150

$\ldots|\ldots| \ldots|\ldots| \ldots|\ldots| \ldots|\ldots| \ldots|\ldots| \ldots|\ldots| \ldots \mid$

CGACGCGAGGCGAGAGC--CCTCTTCGCGGGGGCCCATCGTCGACCGATC $\ldots \ldots \ldots \ldots \ldots$. . . . . . . . . .

$\ldots$ G......... . . .--A... . . . . . . . . . . . . .

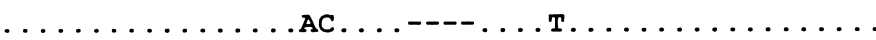

$160 \quad 170 \quad 180 \quad 190 \quad 200$

$\ldots|\ldots| \ldots|\ldots| \ldots|\ldots| \ldots|\ldots| \ldots|\ldots| \ldots|\ldots|$

E. fluviatilis CTATTCACTTGTGAAGGGATCGAGTGAGAGCGTGCCTGTTGCGACCCGA
E. muelleri

S. lacustris

E. fragilis

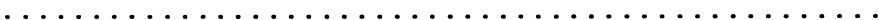

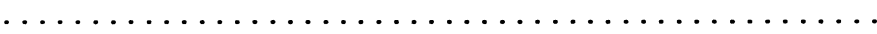

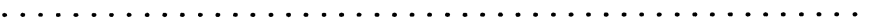

$210 \quad 220 \quad 230 \quad 240 \quad 250$

$\ldots|\ldots| \ldots|\ldots| \ldots|\ldots| \ldots|\ldots| \ldots|\ldots| \ldots|\ldots|$

E. fluviatilis AAGATGGTGACTATGCCTGAGTAGGGTGAAGCCAGAGGAAACTCTGGTG

E. muelleri

S. lacustris

E. fragilis
270

280

290

300

$\ldots$ GAAGCTCGTAGCGATTCTGACGTGCAAATCGATCGTCAAACTTGGGTATA

E. Eluviatilis

E. muelleri

S. lacustris

E. fragilis

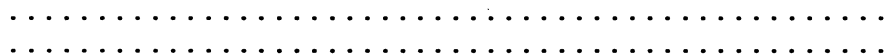

310

320

330

340

$\ldots|\ldots| \ldots|\ldots| \ldots|\ldots| \ldots|\ldots| \ldots|\ldots| \ldots|\ldots|$

E. fluviatilis

GGGGCGAAAGACTAATCGAACCATCtagtagctggttccctccga

E. muelleri

S. lacustris

E. fragilis

Fig. 1. Alignment of the extended 28S rDNA D3 domains from Ephydatia fluviatilis, Ephydatia muelleri, Spongilla lacustris, and Eunapius fragilis. 
The DNA analysis showed the presence of three freshwater sponge species in Estonia: Ephydatia fluviatilis (found at Parmuveski and at Sulbi, the Võhandu River), Ephydatia muelleri (found at Sulbi, the Võhandu River), and Spongilla lacustris (found in the Sulaoja River). The sequenced DNA fragments of the samples collected in Estonia showed an identity with those from the corresponding spongillid type species collected in Belgium.

\section{Electron microscopy based sponge identification}

Three types of siliceous spicules were analysed for sponge identification using scanning electron microscopy: megascleres, which make up the primary framework of a sponge skeleton; microscleres, which are spicules of smaller sizes; and gemmuloscleres, which arm the gemmules - the resting bodies of sponges. Examples of the spicule morphology of the preparations analysed are presented in Fig. 2.

The specimens of S. lacustris collected on 22 September were without gemmules and only those collected on 6 October had developed gemmules. Figure 2a shows a megasclere and a gemmulosclere, both matching the description of S. lacustris (Penney \& Racek, 1968; Manconi \& Pronzato, 2002). Megascleres were straight or slightly curved smooth oxeas (Fig. 2a); gemmuloscleres (see also Fig. 2b) were slightly to strongly curved oxeas or strongyles, covered with large curved spines. Microscleres (Fig. 2c-e) were slightly curved oxea, entirely covered with small spines of asterose shape (Penney \& Racek, 1968; Manconi \& Pronzato, 2002).

The specimens of E. fluviatilis collected on 6 October had not developed any gemmules yet. The genus Ephydatia has no microscleres (Manconi \& Pronzato, 2002). The megascleres (Fig. 2f) were entirely smooth, typically slightly curved oxea, in some cases strongly bent, even to a right angle (not shown).

The third species, E. muelleri, displayed several variabilities in its spicular structure. The megascleres were slightly curved oxea, mostly smooth but often armed with small pointed spines (Fig. $2 \mathrm{~g}$ ); in some cases the tips of armed megascleres were free of spines (Fig. 2h). This type of megascleres is the most common one for E. muelleri according to Penney \& Racek (1968) and Pronzato $\&$ Manconi (2001). The style forms of megascleres (rounded at one end and pointed at the other end) and spicules with three axes were also found (not shown). Gemmuloscleres (Fig. 2i-1) were birotules with a thick smooth shaft and rotules of similar diameter. The shaft $(6-8 \mu \mathrm{m})$ was significantly shorter than that $(12-20 \mu \mathrm{m})$ described by Penney \& Racek (1968), but corresponded to that (5$10 \mu \mathrm{m})$ described by Pronzato \& Manconi (2001). The rotules were irregularly and deeply incised into long irregular rays, whose number was typically from 6 to 9. Every ray of the same rotule was either smooth or armed with spines of variable frequency (Fig. 2i-k). A fine structure of a tip of a gemmulosclere ray is demonstrated in Fig. 21. 


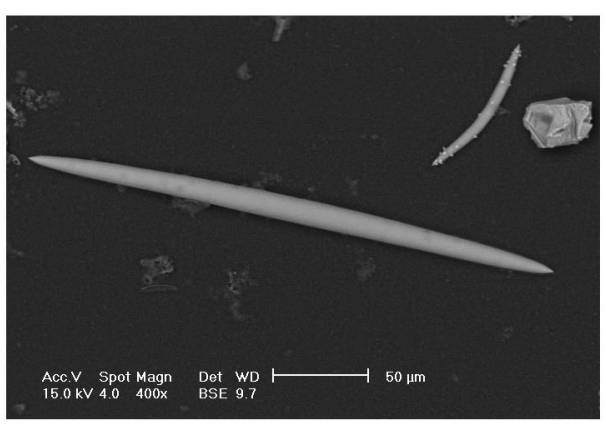

a

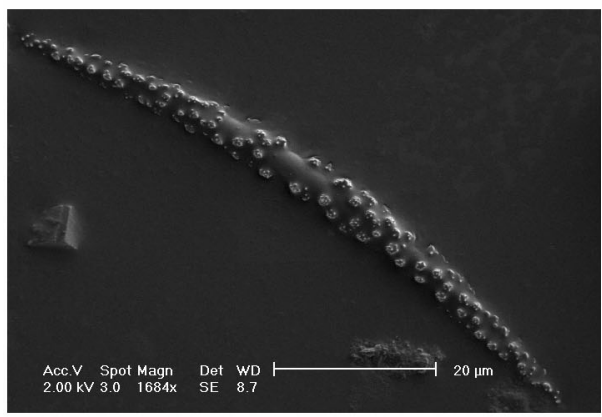

c

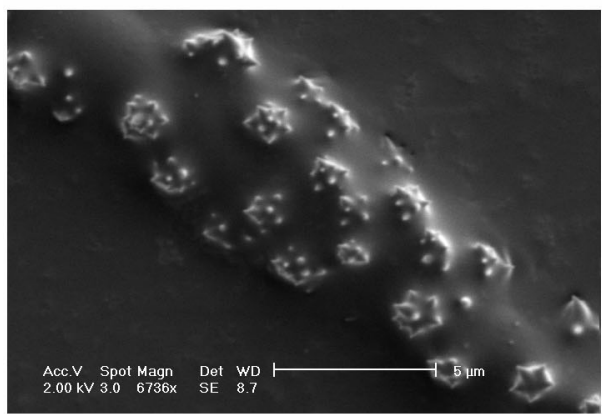

$\mathrm{e}$

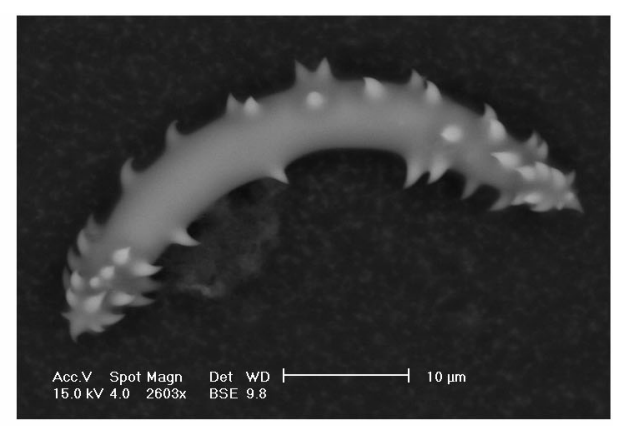

b

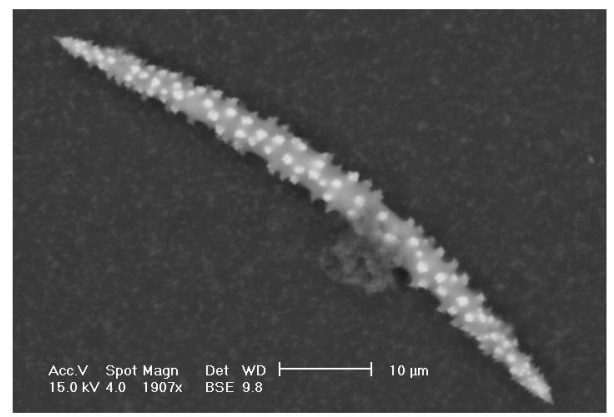

d

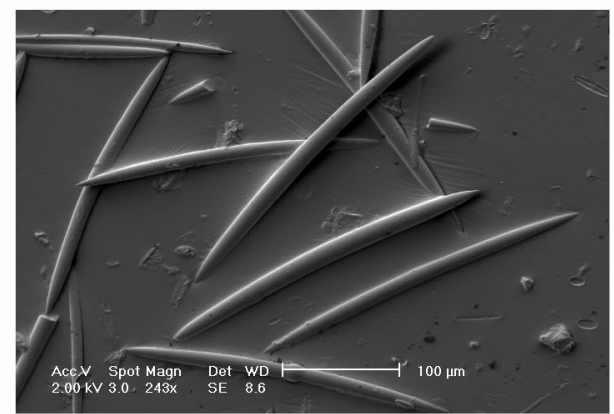

f

Fig. 2. Spicule types of sponges collected in South Estonia. S. lacustris: a - megasclere smooth oxea (a gemmulosclere is also present), b-spiny gemmulosclere, $\mathrm{c}-\mathrm{e}$ - microscleres acanthoxeas; E. fluviatilis: $\mathrm{f}-$ megascleres smooth oxeas; E. muelleri: $\mathrm{g}, \mathrm{h}$ - megascleres spiny and smooth oxeas (birotules gemmuloscleres are also present), $\mathrm{i}$ - birotule gemmulosclere, $\mathrm{j}$ - rotules of gemmuloscleres, $\mathrm{k}$ - birotule gemmulosclere variants, 1 - a detail of a rotule, zoomed $(\mathrm{a}, \mathrm{b}, \mathrm{d}, \mathrm{h}, \mathrm{k}$ - uncoated preparations; c, e, f, g, i, j, l- preparations coated with gold). 


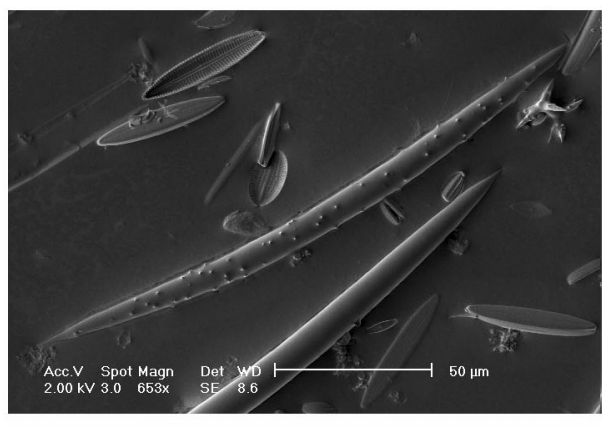

g

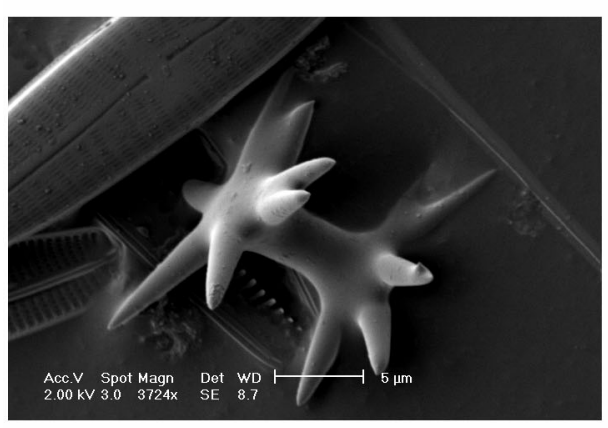

i

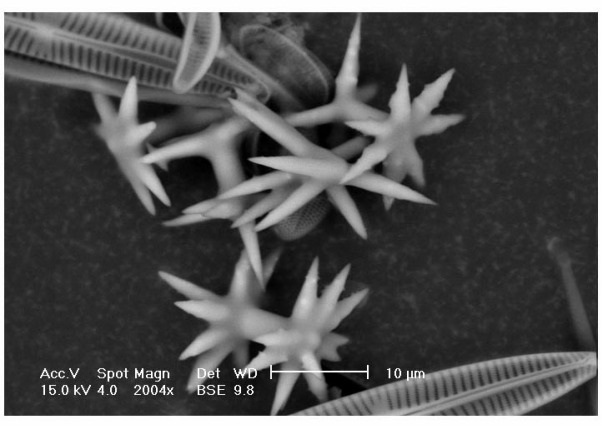

$\mathrm{k}$

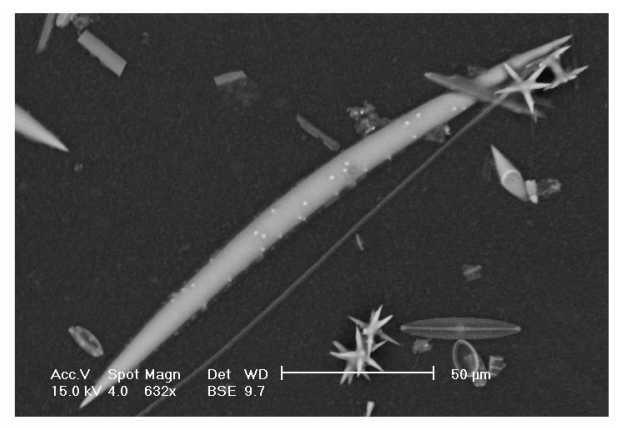

$\mathrm{h}$
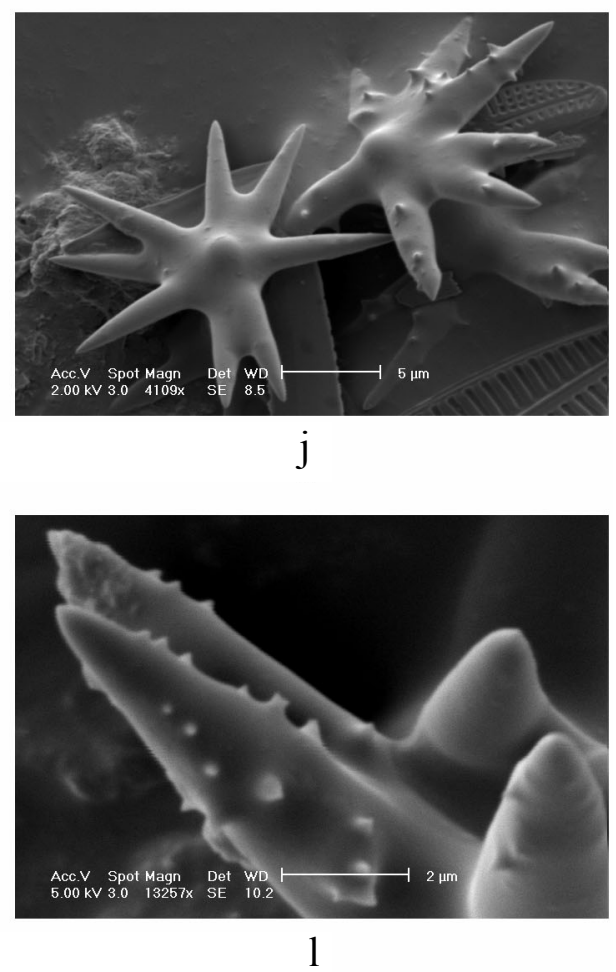

Fig. 2. Continued. 


\section{DISCUSSION}

The identification of sponges has traditionally been based on their morphological characters, among which the skeletal architecture and spicule composition have been of particular importance. With the introduction of molecular techniques a new perspective was opened for the classification of sponges. The nucleotide sequences of $18 \mathrm{~S}$ rDNA and partial nucleotide sequences of $28 \mathrm{~S}$ rDNA have been used for the analysis of the sponge molecular phylogeny (Alvarez et al., 2000; Borchiellini et al., 2004, Nichols, 2005). Sipkema et al. (2003) used the whole $18 \mathrm{~S}$ rDNA sequence to identify the sponge cells in a primary sponge-cell culture contaminated with other eukaryotic organisms. The discrimination between sponge species, based on their 18S rDNA, is more difficult due to a small number of variable sites dispersed all over the sequence. For this purpose the $28 \mathrm{~S}$ rDNA is more reliable for the number of variable regions in its molecule, flanked by conserved sequences. We used one of these variable regions, D3 domain from $28 \mathrm{~S}$ rDNA, together with its flanking conservative sequence for the identification of freshwater sponge species as analysed before by Nunn et al. (1996) for monophyletic invertebrate lineage. As the particular data for Spongillidae were missing in the $28 \mathrm{~S}$ Genebank, we first obtained the reference sequences using samples from the sponge type species (Fig. 1). The results confirmed the adequacy of this DNA segment for the discrimination between freshwater sponge species studied. Similarily, Alvararez et al. (2000) used the same 28S rDNA segment for the molecular description of 27 different marine sponge species belonging to the families of Axinellidae, Halichondriidae, Dictyonellidae, Agelasidae, and Astroscleridae (Porifera: Demospongiae).

At least one of the species in this study, E. fluviatilis, has several strains. A strain of E. fluviatilis is defined as the collection of all the individual sponges, the gemmules of which give rise to individuals that are able to fuse together (Rasmont, 1970). The amplification of the D3 28S rDNA domain, which was sufficient for the discrimination between the species belonging to the family Spongillidae, did not reveal genetic differences between individual strains of E. fluviatilis. Other molecular markers should be developed for this purpose. Furthermore, the molecular analysis of highly variable polymorphic regions in sponge genome (including rDNA) would result in appropriate markers for population studies.

In parallel with the genetic analysis we performed classical microscopic studies of Estonian sponge samples, using a light microscope. The skeleton of sponges provides the most useful set of characteristics for their identification. The diverse range of kind and size of spicules, in particular those present in gemmules (gemmuloscleres) makes them an indispensable means for a sponge taxonomist (Hooper \& van Soest, 2002). Not all freshwater sponges make gemmules for their overwinter survival; in the genera Spongilla, Ephydatia, and Eunapius belonging 
to the family Spongillidae gemmulation takes place. We were able to distinguish between megascleres, microscleres, and gemmuloscleres in our preparations, using a common light microscope. Unfortunately, the sample of E. fluviatilis that was collected on 6 October was without gemmules. Obviously the period of gemmulation had not started yet. This is in accordance with the observation of Van de Vyver \& Willenz (1975) that the gemmulation period in E. muelleri starts earlier than in E. fluviatilis.

Though the resolution of a light microscope is usually sufficient for the morphological analysis of sponge spicules, in some cases the discrimination between certain species, e.g. Spongilla lacustris and Eunapius fragilis, may be difficult (Richelle-Maurer et al., 1994). So we confirmed the results of light microscopy by using scanning electron microscopy, which permits to characterize fine ultrastructural features of spicule morphology (Fig. 2a-1).

We have previously described the presence of ATP N-glycosidase activity, discovered in the marine sponge Axinella polypoides (Reintamm et al., 2003), in the extracts of several Belgian freshwater sponges, grown from gemmules in vitro in Petri dishes (Kelve et al., 2004). The studies of the samples of E. fluviatilis collected from the Võhandu River confirmed the presence of this unique enzymatic activity in a sponge body in its natural conditions (data not shown).

The sponge samples analysed in this work were collected at several sites in two rivers of South Estonia. They were found on stones at a depth of less than $1 \mathrm{~m}$ in places of fast flow. The habitats of different species, particularly E. fluviatilis and E. muelleri, may be located very close to each other (at Sulbi). Historical references have been given to several other sponge habitats in Estonia. Spongilla lacustris has been found in several lakes in addition to rivers, including the recent past (based on the data of H. Timm, www.seiremonitor.ee). Also, Ephydatia sp. has been found to live in some lakes (Riikoja, 1955; Ristkok \& Ruse, 1962). As the Estonian sponge population has not been studied extensively, it is highly probable that not all the sponge species have been reported thus far. The literature data suggest that the geographic distribution of the genera Ephydatia, Spongilla, and Eunapius is worldwide, including the area of Estonia (Manconi \& Pronzato, 2002).

The present work provides for the first time molecular expertise for the identification of Estonian freshwater sponges, contributing to the systematic studies on the distribution and abundance of the freshwater invertebrate fauna in Estonia.

\section{ACKNOWLEDGEMENTS}

This work was supported by the Estonian Science Foundation (grant No. 5932). We thank Dr. Kai Piirsoo for introducing us to sponge habitats and Dr. Meelis Toomet for helping with the scanning electron microscopy technique. 


\section{REFERENCES}

Alvarez, B., Crisp, M. D., Driver, F., Hooper, J. N. A. \& Van Soest, R. W. M. 2000. Phylogenetic relationship of the family Axinellidae (Porifera: Demospongiae) using morphological and molecular data. Zool. Scr., 29, 169-198.

Borchiellini, C., Chombard, C., Manuel, M., Alivon, E., Vacelet, J. \& Boury-Esnault, N. 2004. Molecular phylogeny of Demospongiae: implications for classification and scenarios of character evolution. Mol. Phylogenet. Evol., 32, 823-837.

Dybowski, W. 1878. Über die Spongillen der Ostseeprovinzen. Sitzungsberichte der NaturforscherGesellschaft zu Dorpat, IV, 524-534.

Hooper, J. N. A. \& van Soest, R. W. M. (eds). 2002. Systema Porifera: A Guide to the Classification of Sponges. Kluwer Academic/Plenum Publishers, New York.

Järvekülg, A. 1995. Veeselgrootud. In Eesti. Loodus (Raukas, A., ed.), pp. 441-452. Valgus/Eesti Entsüklopeediakirjastus, Tallinn.

Kelve, M., Lopp, A., Reintamm, T., Kuusksalu, A., Van de Vyver, G. \& Richelle-Maurer, E. 2004. Freshwater sponge cell cultures as model systems for biochemical pathways present in marine sponges. Aquaculture Europe '04: Biotechnologies for Quality. EAS Special Publication No. 34, 459-460.

Kuusksalu, A., Pihlak, A., Müller, W. E. G. \& Kelve, M. 1995. The (2'-5')oligoadenylate synthetase is present in the lowest multicellular organisms, the marine sponges. Demonstration of the existence and identification of its reaction products. Eur. J. Biochem., 232, 351-357.

Manconi, R. \& Pronzato, R. 2002. Suborder Spongillina subord. nov.; Freshwater sponges. In Systema Porifera: A Guide to the Classification of Sponges, Vol. 1 (Hooper, J. N. A. \& van Soest, R. W. M., eds), pp. 921-1019. Kluwer Academic/Plenum Publishers, New York.

Mühlen, M. von zur \& Schneider, G. 1920. Der See Wirtzjerw in Livland. Archiv für die Naturkunde des Ostbaltikums, 14(1), 14.

Müller, W. E. G., Wiens, M., Adell, T., Gamulin, V., Schröder, H. C. \& Müller, I. M. 2004. Bauplan of urmetazoa: basic for genetic complexity of metazoa. Int. Rev. Cytol., 235, 53-92.

Murray, M. G. \& Thompson, W. F. 1980. Rapid isolation of high molecular weight plant DNA. Nucleic Acids Res., 8, 4321-4325.

Nichols, S. A. 2005. An evaluation of support for order-level monophyly and interrelationships within the class Demospongiae using partial data from the large subunit rDNA and cytochrome oxidase subunit I. Mol. Phylogenet. Evol., 34, 81-96.

Nunn, G. B., Theisen, B. F., Christensen, B. \& Arctander, P. 1996. Simplicity-correlated size growth of the nuclear 28S ribosomal RNA D3 expansion segment in the crustacean order Isopoda. J. Mol. Evol., 42, 211-223.

Penney, J. T. \& Racek, A. A. 1968. Comprehensive revision of a worldwide collection of freshwater sponges (Porifera, Spongillidae). U.S. Nat. Hist. Bull., 272, 1-184.

Pronzato, R. \& Manconi, R. 2001. Atlas of European freshwater sponges. Ann. Mus. Civ. St. nat. Ferrara, 4, 3-64.

Rasmont, R. 1970. Some new aspects of the physiology of fresh-water sponges. Symp. Zool. Soc. Lond., 25, 415-422.

Reintamm, T., Lopp, A., Kuusksalu, A., Pehk, T. \& Kelve, M. 2003. ATP N-glycosidase. A novel ATP-converting activity from a marine sponge Axinella polypoides. Eur. J. Biochem., 270, 4122-4132.

Richelle-Maurer, E., Degoudenne, Y. \& Van de Vyver, G. 1994. Some aspects of the ecology of Belgian freshwater sponges. In Sponges in Time and Space. Biology, Chemistry, Paleontology (van Soest, R. W. M., van Kempen, T. M. G. \& Braekman, J.-C., eds). Proc. 4th Intern. Porifera Congress., pp. 341-350. Balkema, Rotterdam.

Riikoja, H. 1955. Eesti NSV selgrootute fauna uurimise küsimusi. Loodusuurijate Seltsi aastaraamat, 48, 7-26. 
Ristkok, J. 1994. Emajõe veestiku vooluvetest leitud hüdrobiondid. Eesti Loodusuurijate Seltsi aastaraamat, 75, 97-147.

Ristkok, J. \& Ruse, K. 1962. Võrtsjärve litoraali põhjafauna koosseisust ja levikust. TRÜ Toim., $120,3-52$.

Sipkema, D., Heilig, H. G. H. J., Akkermans, A. D. L., Osinga, R., Tramper, J. \& Wijffels, R. 2003. Sponge-cell culture? A molecular identification method for sponge cells. Mar. Biotechnol., 5, 443-449.

Timm, H. 1998. Roheline, haruline, auguline. Eesti Loodus, 10, 453.

Van de Vyver, G. \& Willenz, Ph. 1975. An experimental study of the life-cycle of the freshwater sponge Ephydatia fluviatilis in its natural surroundings. Wilhelm Roux' Archiv, 177, 41-52.

van Soest, R. 2001. Identification and classification. In van Soest, R., Richelle-Maurer, E., Gomez, R. \& Braekman, J.-C. Protocols for Developing Sponge Compounds Involving the Source Organism. Final Report Symbiosponge Project, Chapter 1, pp. 13-35 (www.science.uva.nl/ZMA/Invertebrates/Symbiosponge/rep\&pub/protocols.htm).

\section{Eesti mageveekäsnad: geneetiline ja morfoloogiline identifitseerimine}

\section{Tiiu Roovere, Annika Lopp, Tõnu Reintamm, Anne Kuusksalu, Evelyn Richelle-Maurer ja Merike Kelve}

Mageveekäsnade (Porifera, Demospongiae, Haplosclerida, Spongillina) proovid on kogutud Võhandu jõest Sulbilt ning Parmuveskilt ja Sulaojast Krüüdneri lähistel. Uuritavad käsnaliigid on identifitseeritud molekulaarse analüüsi abil. Selleks on määratud esmalt autentsete käsnade Ephydatia fluviatilis, Ephydatia muelleri, Eunapius fragilis ja Spongilla lacustris 28S rDNA D3-domäänide nukleotiidsed järjestused ja võrreldud neid seejärel uuritavatest proovidest eraldatud DNA vastavate järjestustega. On tuvastatud kolme käsnaliigi - Ephydatia fluviatilis, Ephydatia muelleri ja Spongilla lacustris - esinemine Eestis. Saadud tulemusi kinnitab ka käsna toest moodustavate räniokiste morfoloogiline analüüs skaneeriva elektronmikroskoopia meetodil. 